\title{
CENTRIFUGAL COMPRESSOR EFFICIENCY CALCULATION WITH HEAT TRANSFER
}

\author{
VALERIU DRĂGAN \\ Computational Fluid Dynamics Department, INCDT Comoti, \\ Iuliu Maniu 220D, Sect. 6, Bucharest, Romania. \\ Corresponding author: drvaleriu@gmail.com \\ (Received: $11^{\text {th }}$ July 2016; Accepted: 15 ${ }^{\text {th }}$ June 2017; Published on-line: $1^{\text {st }}$ Dec. 2017
}

\begin{abstract}
In this paper we present a case study of apparent performance variation of an optimized centrifugal compressor design when its metal parts are cold - before the conjugated heat transfer between the fluid and parts reaches an energetic equilibrium. The methods used are numerical, using full viscous 3D computational fluid dynamics with heat transfer. Three cases were considered, an adiabatic wall baseline, an all-blade cooling at $293 \mathrm{~K}$ and a more realistic stator row cooling at $293 \mathrm{~K}$. Results indicate an apparent yet erroneous isentropic efficiency reading increase beyond $100 \%$ - which was to be expected due to the fluid cooling. However the isentropic and polytropic efficiencies could be estimated and were used to more accurately assess the performance of the compressor. Power consumption decreased to approximately $97 \%$ of the original load while the pressure ratio was marginally increased. This alone does not, however, explain the non-physical efficiency readings, which are mainly due to the assumptions and manner under which the efficiency itself is calculated. The paper presents a more robust approach to measuring efficiency, regardless of the heat transfer within the turbomachinery itself. Possible applications of the study may range from cold-start regime simulation to the optimization of inter-cooling setup or even flow angle control without mechanically actuated OGV.
\end{abstract}

ABSTRAK: Kertas ini membincangkan tentang kajian kes ke atas perubahan jelas pada rekaan pemampat sentrifugal yang dioptimumkan ketika logam disejukkan - sebelum berlaku perubahan pemindahan haba ke atas bahagian tersebut antara keadaan cecair dan takat keseimbangan tenaga. Kaedah yang digunakan adalah numerikal, dengan menggunakan pengiraan kelikatan penuh cecair 3D dinamik melalui perubahan tenaga. Tiga kaedah telah diambil kira, iaitu: garis pemisah adiabatik, penyejukan pada semua bilah pada suhu $293 \mathrm{~K}$ dan pendekatan yang lebih realistik iaitu baris stator yang disejukkan pada suhu $293 \mathrm{~K}$. Keputusan mendapati kesalahan kenaikan bacaan yang jelas pada ketepatan bacaan isentropik melebihi $100 \%$ - keputusan ini telah dijangka akan berlaku disebabkan oleh kesan penyejukan cecair. Walau bagaimanapun, ketepatan isentropik dan politropik boleh dianggarkan dan telah digunakan untuk menilai ketepatan prestasi pemampat. Penggunaan tenaga telah berkurangan sebanyak $97 \%$ daripada beban asal, sementara nisbah tekanan telah bertambah sedikit. Perkara ini, walau bagaimanapun tidak dapat menjelaskan bacaan yang tepat pada perkara yang tidak bersifat fizikal, kebiasaannya berlaku disebabkan oleh andaian dan cara ketepatan bacaan itu dikira. Kertas ini membentangkan pendekatan yang lebih mantap untuk mengukur ketepatan, tidak kira sama ada ketika pemindahan haba berlaku di dalam mesin turbo itu sendiri. Aplikasi yang berkaitan kerja ini mungkin termasuk bermula dari simulasi rejim mulasejuk (cold-start), sehingga kepada antara persediaan penyejukan ataupun kawalan darjah aliran penyejukan tanpa mesin gerakan OGV.

KEYWORDS: turbo machinery; centrifugal compressor; inter cooler; intra-cooler; SST 


\section{INTRODUCTION}

Industrial compressor designs typically include inter-cooling devices in order to reduce the mechanical work for compression and to increase the efficiency of the entire compression process $[1,2]$. Since space is always a limiting factor not only in aeroengines but also in industrial turbomachinery, an intracooler (i.e. a cooler within the stage itself) might reduce the size of the machine itself and/or improve the inter-stage cooling efficiency and reduce power consumption. Defining efficiency proves to be difficult in applications where the heat transfer occurs either inside the rotary part, as is the case here, or in a very tight package - inaccessible with temperature and pressure probes, as is the case in small turbochargers [3] or electronic appliances [4]. Being unable to separate heat transfer effect from thermal effects associated with the compression (or, indeed expansion) presents a distinct problem which will be addressed herein.

Therefore, a novel approach to determining a more practical definition of isentropic and polytropic efficiency is developed. Moreover, an argument is made regarding possible applications of these effects such as thermal flow control of both friction and flow angles

This paper deals with such an industrial four stage compressor with a nominal air mass flow in excess of $4 \mathrm{~kg} / \mathrm{s}$. Each stage has a centrifugal rotor, vaned diffuser crossover, discharge plenum and intercooler followed by a plenum to remove condensed moisture. Figure 1 presents the schematic of a centrifugal compressor having its architecture topologically equivalent the one currently discussed in [5].

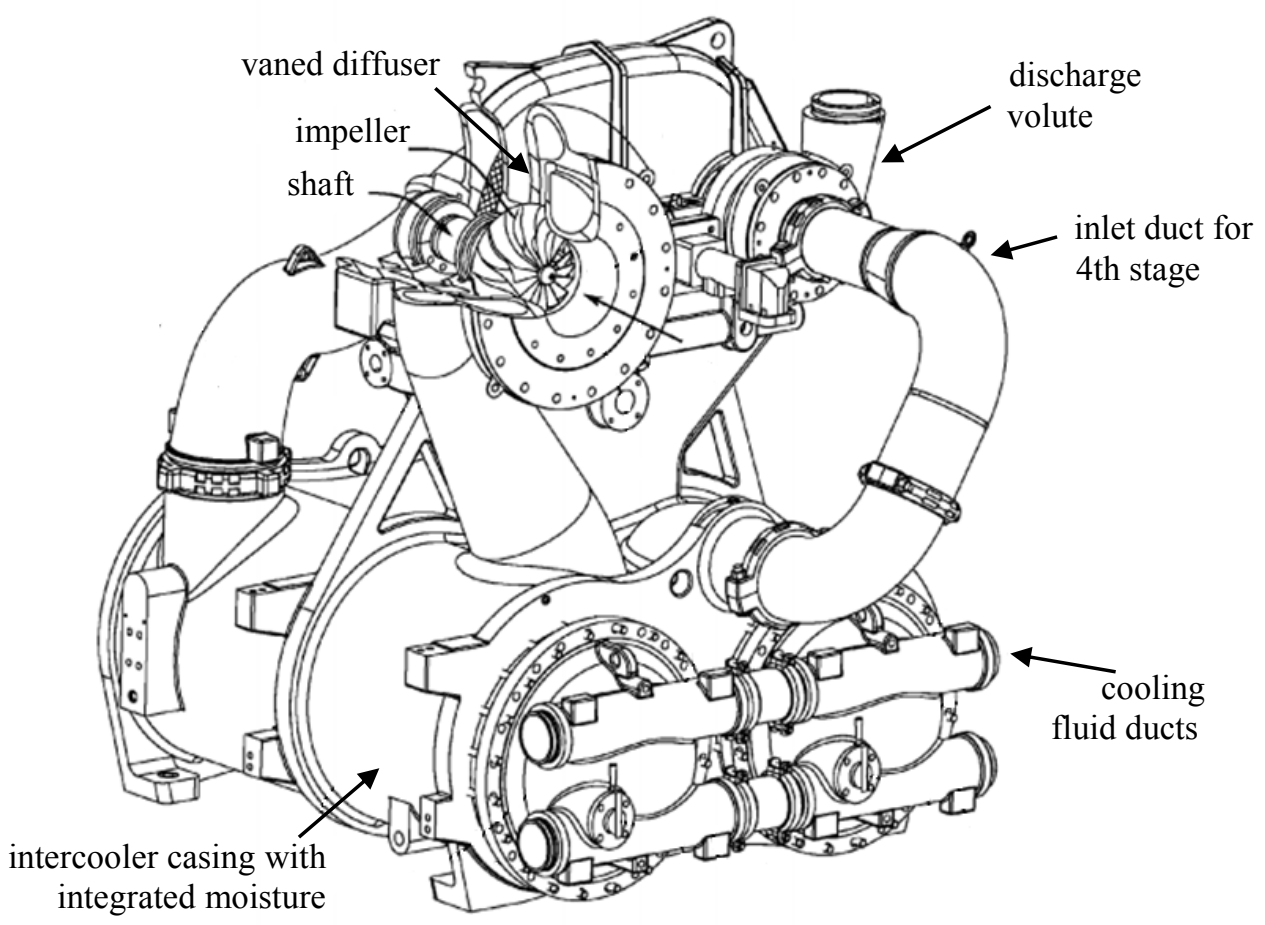

Fig. 1: The generic configuration of the compressor discussed adapted from [5].

We will only refer to the last, high pressure stage, having a rotating speed of 3215 $\mathrm{rad} / \mathrm{s}$, an inlet temperature of $313 \mathrm{~K}$, which is regulated by the previous stage intercooler, and a total inlet pressure of $800000 \mathrm{~Pa}$. The intercooler itself uses water at $293 \mathrm{~K}$ as a cooling agent which passes through a tubular circuit cooling the compressed air flowing out of the diffuser. Typically intercoolers have been used to lower the temperature - hence 
workload - for the downstream compressor stage. In the cases presented herein, the cooling occurs during the actual compression process - hence the assumption that an ideal process should be isentropic is no longer valid, leading to anomalous readings.

The paper attempts to answer the question of how to monitor - in an acceptable manner - the efficiency of the compressor during start-up, when the metal parts affect the readings by essentially cooling the working fluid for a brief period of time. The sources of the anomalous efficiency readings and suggested corrective actions will be presented in the following sections.

Another question refers to the actual influence of cooling distribution across the stage in the overall power consumption and achieving the target pressure ratio. Preliminary findings show that pressure ratios will not be adversely influenced by the infracooling and that power consumption may be slightly lowered particularly if the rotor is cooled.

For this particular case study, a known optimized centrifugal compressor stage was considered [6]. The stage has been recently designed using a combination of an genetic algorithm [7] and an artificial neural network [8]. In paper [6], one of the conclusions reached was that the aerodynamic performance of the compressor cannot be significantly further increased by maintaining the conventional architecture of the compressor and that the thermodynamic losses were the limiting factor in improving its isentropic efficiency. One argument for the use of the stage is that it has also been manufactured and is currently in use, therefore experimentally confirming the CFD results obtained for the baseline.

A secondary purpose of this paper is to examine the influence of rotor and stator cooling effect occurring with cold starts. During the initial experimentation phase a calculated efficiency exceeding $100 \%$ was obtained for a brief but sustained period of time during the starting. This was attributed not to faulty data acquisition - since the efficiency reading eventually stabilized at the expected value for respective speed line. Instead, an alternative explanation that the flow experienced a temporary cooling effect due to the fact that the compressor parts were at a temperature of $293 \mathrm{~K}$, hence the total temperature of the outflow was influenced.

\section{THE COMPUTATIONAL FLUID DYNAMICS METHODOLOGY}

For the CFD study, Numeca's Fine/Turbo structured solver was used with a mesh having the properties described in Table 1. The turbulence model chosen was the k-omega SST $[9,10]$, due to its proven accuracy in various other turbomachinery applications [1113]. To simplify matters, the simulations were carried out using steady-state RANS with constant temperature of $293 \mathrm{~K}$ at the cooled walls and adiabatic walls in all the others.

Prior to the simulation of the thermal transfer between the compressor walls and the working fluid, a grid sensitivity test was carried out. Multiple mesh sizes were tested, monitoring both the global results - such as total to total pressure ratio and efficiency as well as the quality of the interface between the rotating and stationary domain. The sensitivity study was started with a coarse mesh and its density was increased. Due to the tip gap of the rotor, the topology of the blocking structure differs for the rotating and stationary domains. The mesh density was increased keeping the rotor and stator interface cells as closely synchronized as possible in order to minimize interpolation loss [14]. Another parameter of interest was the isentropic efficiency difference on the two sides of the interface - this is has a purely numerical cause and is due to a less than perfect approximation of the flow parameters in the interface model. The skewness, along with other mesh quality indicators, was also monitored in all meshes and the values were found 
to be generally good, considering the complexity of the geometry. The few cells which are less than the typically recommended values for skewness are still above the minimal value accepted by the solver [14]. Moreover, for heat transfer applications, a skewness level of the order used in the current simulations was considered acceptable [15], which present a mesh dependency study in which the maximum skewness of the fine mesh was 0.33 (*the actual value given was 0.57 but this is due to a converse definition of skewness which considers the perfect cell skewness at 0.00 ).

Table 1 presents the skewness of three representative meshes used for the grid sensitivity tests, the criterion is fully presented in [16] and is implemented by Ansys in ICEM CFD [17]. As seen in Table 2, the differences between the CFD results obtained with the fine mesh and the mesh which was used is lower than 0.0025 , which is considered below the margin of error for typical RANS simulations.

Three cases were simulated, the baseline - having all adiabatic walls, a fully cooled stage - having all walls with a constant temperature of $293 \mathrm{~K}$ and a final, more realistic case, having only the stator walls cooled to $293 \mathrm{~K}$.

In Fig. 2 a meridional view of the computational domain is shown, comprising of compressor inlet, rotor, vaneless diffuser, vaned diffuser - which covers the $90^{\circ}$ crossover, plenum space and outlet. Note that in this case the actual intercooler which is downstream of the compressor is not modeled.

Table 1: Mesh quality statistics for three of the meshes used for grid sensitivity checked with Ansys ICEM-CFD

\begin{tabular}{cccc}
\hline Skewness & Coarse mesh & $\begin{array}{c}\text { Intermediate } \\
\text { mesh }\end{array}$ & Fine mesh \\
\hline 1 & 531034 & 810691 & 1346979 \\
0.95 & 233388 & 483557 & 600717.5 \\
0.9 & 191381 & 286110 & 417272.5 \\
0.85 & 122641 & 194958 & 253901.3 \\
0.8 & 73621 & 135338 & 165965 \\
0.75 & 92252 & 96458 & 177991.3 \\
0.7 & 57797 & 64907 & 111066.3 \\
0.65 & 21618 & 38638 & 36200 \\
0.6 & 10428 & 19780 & 19460 \\
0.55 & 4610 & 9543 & 7775 \\
0.5 & 1817 & 2926 & 2109 \\
0.45 & 511 & 405 & 292 \\
0.4 & 166 & 305 & 0 \\
0.35 & 16 & 200 & 0 \\
0.3 & 0 & 54 & 0 \\
0.25 & 0 & 0 & 0 \\
0.2 & 0 & 0 & 0 \\
0.15 & 0 & 0 & 0 \\
0.1 & 0 & 0 & 0 \\
0.05 & 0 & 0 & 0 \\
total cells & 1341280 & 2143870 & 3139729 \\
\hline
\end{tabular}


Table 2: Mass averaged total temperature and pressure taken at stage outlet and the isentropic efficiency calculated based on them.

\begin{tabular}{cccc}
\hline Case & $\boldsymbol{T}_{\text {stage }}^{*}$ & $\boldsymbol{p}_{\text {stage }}^{*}$ & $\boldsymbol{\eta}_{\text {isent }}^{*}$ \\
\hline Fine mesh & 403.7 & 1730020 & 0.850764 \\
Intermediate & 403.454 & 1730350 & 0.853313 \\
Coarse mesh & 402.6 & 1735020 & 0.864801 \\
\hline
\end{tabular}

Figure 3 presents a view of the surface mesh of a rotor and a stator flow channel; mesh smoothing was used to increase the orthogonality of the mesh as well as the growth ratio of the cells from the near wall cell to the periodic boundary. The mesh is conformal at the tip as well as at the periodic interfaces.

Although the notion of solution convergence depends heavily on the goals of the case and on the user's personal choice of criteria [18], certain general guidelines were employed in determining a stopping point to the simulations. Thus, the residual values were monitored and stabilized at around 10-3.9, the pressure ratio fluctuations less than $0.3 \%$, and mass flow imbalance below $0.4 \%$ in all the three cases presented.

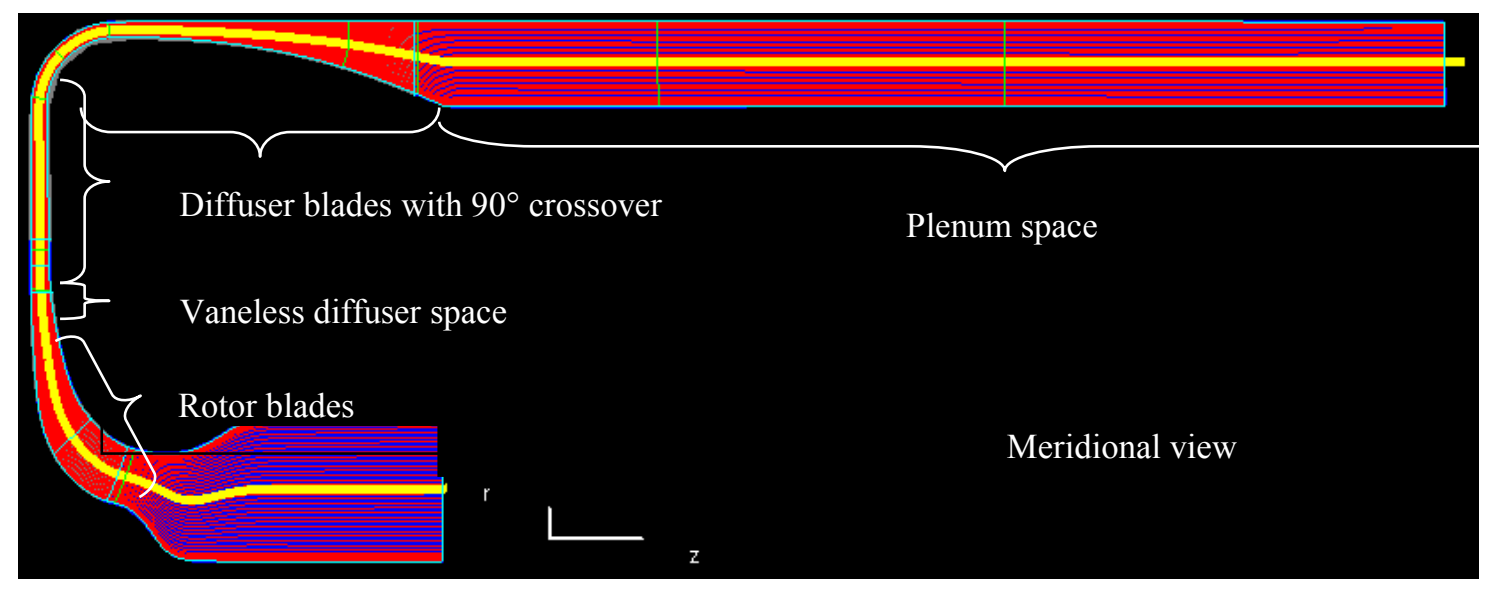

Fig. 2: Flow channel of the stage considered, streamlines on medium mesh used.

In terms of convergence, the several parameters which were continuously monitored during each run in order to insure that the relevant parameters have stopped evolving (i.e. their instantaneous values were fluctuating with a stable amplitude and frequency above the same average for almost 2000 iterations) before the case was considered converged.

(a)




(b)


Fig. 3: (a) The computational mesh used for the rotor, (b) The stator mesh and details.

Although perhaps not universally applicable, the mass flow imbalance is typically one of the most relevant parameter used in turbomachinery simulations for assessing the solution convergence, along with pressure ratio and isentropic efficiency. Hence, Fig. 4 presents the mass flow differences which were monitored for the three cases mentioned.

Isentropic efficiency in the case of turbomachinery is a parameter used to assess the extent to which the compression process (in this particular case) - which is ideally considered to be isentropic - reaches the ideal limit. Therefore it is the expression of the isentropic, rather than polytropic, efficiency which gives the user the estimate power consumption. This is due to the fact that the standard assumption is that the compression process should be adiabatic. Another way of looking at this is that the isentropic efficiency encompasses all losses (aerodynamic and thermodynamic) whereas the polytropic efficiency only accounts for the thermodynamic losses [19-22]. 


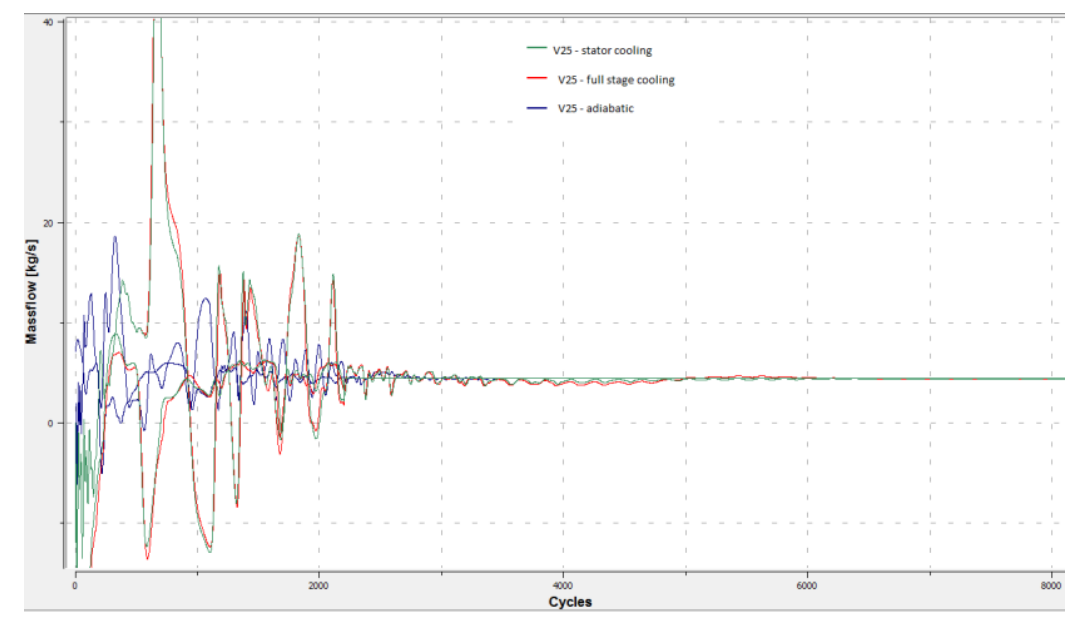

Fig. 4: Mass flow for inlet/outlet for the three cases presented in the current paper.

Isentropic efficiency in the case of turbomachinery is a parameter used to assess the extent to which the compression process (in this particular case) - which is ideally considered to be isentropic - reaches the ideal limit. Therefore it is the expression of the isentropic, rather than polytropic, efficiency which gives the user the estimate power consumption. This is due to the fact that the standard assumption is that the compression process should be adiabatic. Another way of looking at this is that the isentropic efficiency encompasses all losses (aerodynamic and thermodynamic) whereas the polytropic efficiency only accounts for the thermodynamic losses [19-22].

In order to assess the isentropic efficiency, an alternative equation was used to Eq. (2), since the total temperature (and enthalpy) was influenced by the heat transfer with the walls.

$$
\begin{aligned}
& \eta_{\text {isent }}^{*}=\frac{\mathrm{T}_{1}^{*}\left(\pi_{C}^{*} \frac{\gamma-1}{\gamma}-1\right)}{\mathrm{T}_{2}^{*}-\mathrm{T}_{1}^{*}} \\
& \eta_{\text {poly }}^{*}=\frac{\frac{\gamma-1}{\gamma} \cdot \lg \left(\pi_{C}^{*}\right)}{\lg \left(\frac{\mathrm{T}_{2}^{*}}{\mathrm{~T}_{1}^{*}}\right)}
\end{aligned}
$$

The alternative isentropic efficiency definition used was deduced from the torque of the shaft and the total-to-total pressure ratio:

$$
\begin{aligned}
& P_{\text {aero }}=\omega \cdot M \\
& P_{\text {aero }}=\dot{m} \cdot C_{p} \cdot \Delta T^{*} \\
& \Delta T^{*}=T_{1}^{*}\left(\frac{\pi_{C}^{*} \frac{\gamma-1}{\gamma}-1}{\eta_{\text {isent }}^{*}}\right) \\
& \eta_{\text {isent }}^{*}=\dot{m} \cdot C_{p} \cdot T_{1}^{*}\left(\frac{\pi_{C}^{*} \frac{\gamma-1}{\gamma}-1}{\omega \cdot M}\right)
\end{aligned}
$$

Based on this, an estimate of the isentropic efficiency was done by using the more relevant parameter of pressure ratio - which is less affected by the heat transfer, as it will be shown further on. Hence, the proposed polytropic efficiency formulation is presented as: 


$$
\eta_{\text {poly }}^{*}=\frac{\lg \left(\pi_{C}^{*} \frac{\gamma-1}{\gamma}\right)}{\lg \left(1+\frac{\pi_{C}^{*} \frac{\gamma-1}{\gamma}-1}{\eta_{\text {isent }}^{*}}\right)}
$$

A note can be made regarding convergence time required for the cooled cases where a significantly higher number of iterations were necessary for the mass imbalance to drop below the $0.4 \%$ margin (which was set as a convergence criterion for all three cases). This is due to the more complex interactions between the flow and the walls - in particular to the convection processes that occur in the turbulent boundary layer. Also, the higher number of iterations required is due to the fact that, in order to stabilize the solver, a CFL number three times lower than for the baseline case was required for the cooled cases.

\section{RESULTS AND DISCUSSION}

Due to the atypical nature of the flow simulations presented, the classical equation for isentropic efficiency - normaly used in actual monitoring of operating compressors - is not usable. This is due to the significantly lower outlet temperature which is in turn due to the heat transfer between the fluid and the compressor walls. As pointed out in [19-22], the isentropic efficiency is especially useful for turbomachinery designers in assessing the aerodynamic losses (rather than just the thermodynamic losses which are assessed by using the polytropic efficiency). Therefore it is important to circumvent the faulty methodology for calculating isentropic efficiency and also to link it to measurable parameters which could be instrumented on real applications.

One way to eliminate this inconvenience is to use the power consumption of the compressor in order to estimate the actual aerodynamic losses. Equations (6) and (7) can be used to determine the isentropic and polytropic efficiency respectively in cases where heat transfer occurs between the working fluid and the machinery walls.

A point must be made that a rigorous equation would have to factor the effort required by the cooling installation which should be considered a source of power loss. For the cases presented, however, the main question to be answered was how to eliminate the anomalous efficiency reading greater than one. Hence heat transfer is not dependent on an external cooler and is hence effortless - from a power consumption perspective. It is worth noting that heat transfer only lasts for a limited period of time, decreasing in intensity until the conjugated heat transfer between the metal parts and the working fluid reaches thermodynamic equilibrium and the walls behave - overall adiabatically.

As expected, the cases where cooling was applied along the stage displayed a higher efficiency and pressure ratio than the baseline which had adiabatic walls. This is in part related to the method in which the isentropic efficiency of the stage is calculated but it also has to do with the fact that the working fluid - having been cooled - requires less compression mechanical work. This having been said, the pressure ratio increased only slightly in the fully cooled case and the only visible differences were observed in the pressure ratio measured at the rotor-stator interface. However, in the fully cooled case, although minor pressure ratio increases were seen, the aerodynamic power consumption dropped to $\sim 96.84 \%$ of the baseline -which could be significant.

Figure 5 presents the $y+$ distribution across the rotor geometry - which is the same for the three cases studied. The plots confirm that the mesh size near the wall was in accordance with the prescriptions of k-omega models which require a less than one unit 
$\mathrm{y}^{+}$. Two aspects were monitored: the aerodynamic losses - which could be accurately estimated through the polytropic efficiency and the thermodynamic process losses - which could only be inferred from the modifications of the flow coefficient and the specific speed. An influence over the torque and pressure ratio was observed in both cases, as well as a reduction in the fluid deviation from the blade at the rotor outlet. Tables 3 and 4 present the global parameters of interest for the three cases. For a more visual comparison, Figure 6 presents a meridional average entropy distribution along the flow channel for the three cases.

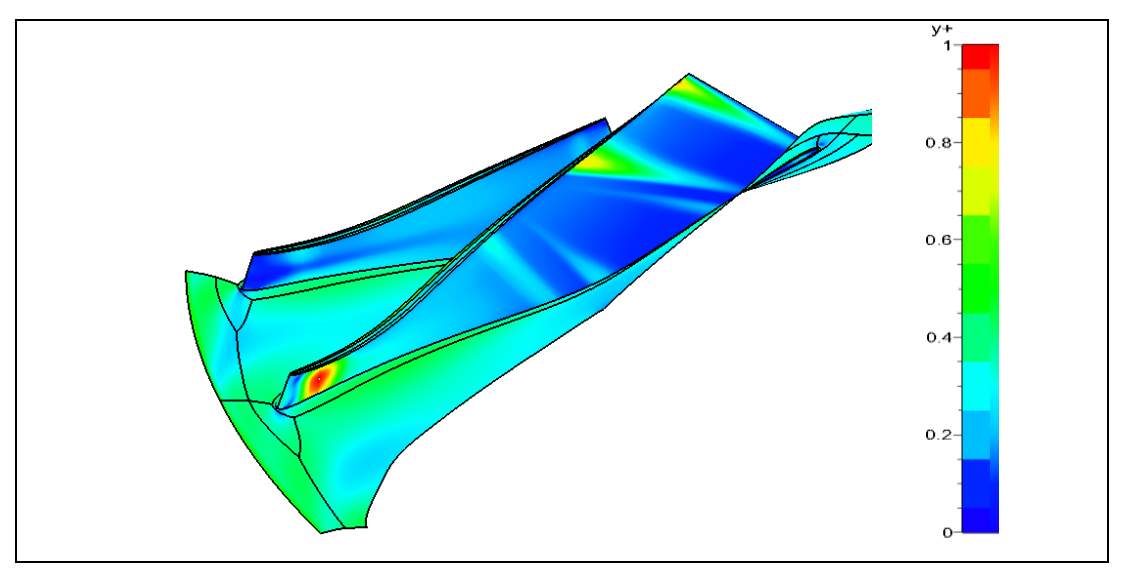

Fig. 5: Dimensionless wall height distribution of the first cell on the rotor for the three cases.

Slip factor, although apparently high - compared to other optimized compressors - is explainable due to the location at which it is measured. Typical correlations [23-25] refer to the exact rotor outlet (in which the fluid has minimal slip), in our cases the measurements were taken in the middle of the distance separating the rotor from the vanes of the diffuser. Therefore, as expected, both efficiency and slip factor measurements were below the values reported by typical optimized rotors. It was felt, however that the measurement point chosen was more representative for the rotor for the practical purpose of estimating the polytropic efficiency using Eq.(7).

Table 3: Global parameter synthesis for rotor-stator interface and stage

\begin{tabular}{cccc}
\hline Rotor-Stator interface & adiabatic & full stage cooling & stator cooling only \\
\hline Specific Speed & 0.4565088 & 0.4658891 & 0.467094 \\
Flow Coefficient & 0.6820208 & 0.6973607 & 0.682961 \\
Isent. Eff. Eq. (1) & 0.9158536 & 1.0136014 & 0.9616 \\
Isent. Eff Eq. (6) & n.a. & 0.967467 & 0.925719 \\
Polyt. Eff. Eq. (2) & 0.9250883 & 1.0120773 & 0.965853 \\
Polyt. Eff. Eq. (7) & n.a. & 0.97110685 & 0.93393505 \\
Slip Factor & 0.7516529 & 0.7678544 & 0.752223 \\
Power [W] & 407086.69 & 394224.55 & 407086.7 \\
Press. Ratio & 2.3001112 & 2.33665 & 2.315713 \\
Axial Thrust & -44930 & -44790 & -45110 \\
\hline
\end{tabular}




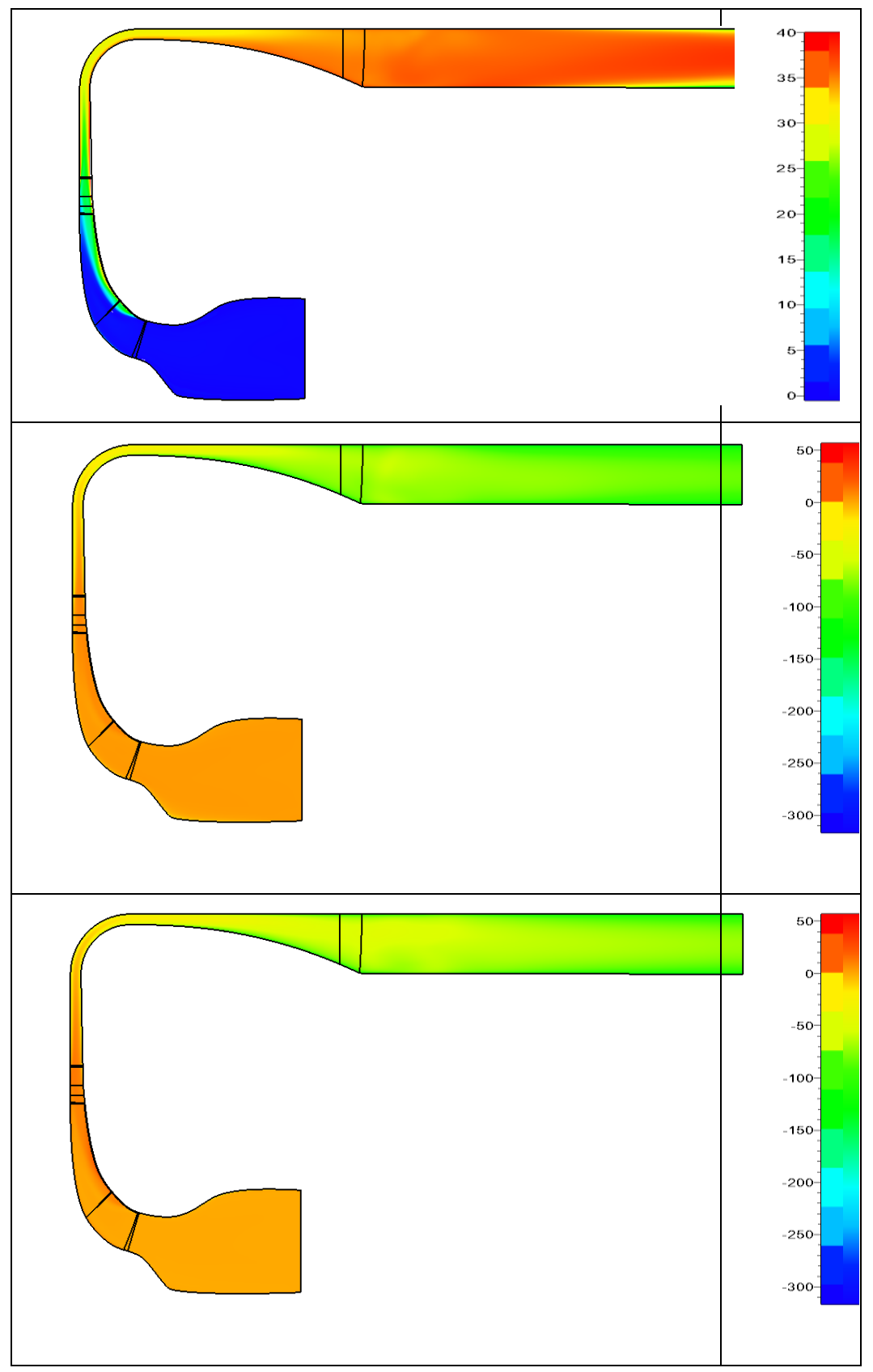

Fig. 6: Entropy distribution along the flow channel adiabatic (top) full cooling (mid) and stator cooling (bottom).

Note how the entropy differs greatly from the case with and without cooling, although it is higher in the case in which the stator alone is cooled. This can be explained due to the high exposure surface aria between the fluid and the stator channel - which dominates the stage in terms of length.

Also significant influences were observed on the slip factor of the cooled rotor and also on the stage outlet flow angle of the fully cooled stage, where the specific speed is defined as:

$N . S .=\frac{\left|\frac{\omega \cdot \pi}{30}\right| \cdot 0.1047 \cdot \sqrt{\dot{m} \cdot T_{1}^{*} \cdot \pi_{C}^{*}}}{\left(c_{P} \cdot 10.718 \cdot \Delta T^{*} \cdot \eta_{\text {poly }}^{*}\right)^{0.75}}$ 
and the flow coefficient as:

$$
\varphi=\frac{\dot{m} \sqrt{R_{\text {air }} T_{1}^{*} / \gamma}}{p_{1}^{*} \cdot \pi \cdot\left(\frac{D_{2}}{2}\right)^{2}} / \frac{\frac{D_{2}}{2} \cdot\left|\frac{\omega \cdot \pi}{30}\right|}{\sqrt{\gamma R_{\text {air }} T_{1}^{*}}}
$$

Table 4: Global parameter synthesis for the entire stage

\begin{tabular}{cccc}
\hline Entire stage & adiabatic & $\begin{array}{c}\text { full stage } \\
\text { cooling }\end{array}$ & $\begin{array}{c}\text { stator cooling } \\
\text { only }\end{array}$ \\
\hline Isentropic Efficiency Eq. (1) & 0.853 & 1.432 & 1.366967 \\
Isentropic Efficiency Eq. (6) & n.a. & 0.897 & 0.86861 \\
Polytropic Efficiency Eq. (2) & 0.869 & 1.386 & 1.328 \\
Polytropic Efficiency Eq. (7) & n.a. & 0.908 & 0.882 \\
Flow Angle (degrees from through flow & & & \\
$\quad$ direction) & 47.67 & 56.52 & 46.2 \\
Pressure Ratio (t-t) & 2.194 & 2.212 & 2.211 \\
Outlet Temperature & 405.274 & 368.633 & 371.254 \\
Velocity Magnitude & 38.7874 & 47.2784 & 39.7024 \\
\hline
\end{tabular}

\section{CONCLUSIONS}

Simulations confirmed that the isentropic efficiency of the stage can be influenced by the heat transfer from the working fluid to the cold metallic parts of the compressor in its cold starting sequence.

The paper presents a new approach, proposing new formulations for the total to total isentropic and polytropic efficiencies in order to eliminate the apparent greater than one efficiency. Herein we take into consideration the consumed aerodynamic power and are therefore not prone to un-physical efficiency estimations.

Although, obviously not as high as estimated by Eqs.(1) and (2), the efficiency of the cooled cases is higher than in the case of adiabatic walls, from the power consumption corroborated with the total pressure ratio.

Total temperature differences are comparable between the two cooled cases while in terms of power consumption, flow angle and absolute velocity, the most significant influence is seen only when the full stage is cooled. When the rotor is cooled the slip factor is significantly changed by the increased through flow velocity in the rotor due to less work necessary for compression. The same goes for the flow coefficient, surprisingly, since the surface aria of the stator has a much higher participation than that of the rotor.

Note that the correlations of polytropic efficiency with the flow coefficient [26] or [27], cannot be applied to the cases where there is heat transfer.

Flow angle influences set the premises of using thermal effects for small turbomachinery applications - such as micro turbine engines where variable geometry would be prohibitive. 


\section{ACKNOWLEDGEMENT}

The author would like to acknowledge the support of the NRDI Comoti for the current research as well as the particular contributions of Eng. Georgel Vizitiu for the overall revamping efforts on the CCAE 21-300 aerodynamics.

\section{REFERENCES}

[1] Teemu T-S, Röyttä P, Honkatukia J, Backman J. (2010) Predicting off-design range and performance of refrigeration cycle with two-stage centrifugal compressor and flash intercooler. International Journal of Refrigeration, 33(6):1152-1160.

[2] Xenos DP, Cicciotti M, Bouaswaig AEF, Thornhill NF, Martinez-Botas R. (2014) Modeling and Optimization of Industrial Centrifugal Compressor Stations Employing Data-Driven Methods, ASME Turbo Expo 2014: Turbine Technical Conference and Exposition, Volume 3B: Oil and Gas Applications; Organic Rankine Cycle Power Systems; Supercritical $\mathrm{CO}_{2}$ Power Cycles; Wind Energy Düsseldorf, Germany, Paper No. GT2014-25089.

[3] Casey M, Robinson C. (2013) A Method to Estimate the Performance Map of a Centrifugal Compressor Stage, Journal of Turbomachinery, 135:021034-1.

[4] Dyson's challenges in turbomachinery design (white paper) (2016) Numeca/ConceptsNREC seminar: Taking your turbomachinery design to the next level.

[5] Gerber TD, Clemons JD. (2014)Centrifugal Compressor Having Cooling System. United States Patent Application 20140356147 A1.

[6] Dragan V, Malael I, Gherman B. (2016) A comparative analysis between optimized and baseline high pressure compressor stages using tridimensional computational fluid dynamics. Engineering, Technology and Applied Science Research, 6(4):1103-1108.

[7] Dragan V. (2014) Aerodynamic reconfiguration and multicriterial optimization of centrifugal compressors-a cases study. INCAS Bulletin, 6(4):41-49 .

[8] Safikhani H, Khalkhali A, Farajpoor M. (2011) Pareto Based Multi-Objective Optimization of Centrifugal Pumps Using CFD, Neural Networks and Genetic Algorithms. Engineering Applications of Computational Fluid Mechanics, 5(1):37-48.

[9] Menter FR, Langtry RB, Likki SR, Suzen YB, Huang PG, Völker S. (2006) A Correlation based Transition Model using Local Variables Part 1- Model Formulation. ASME Journal of Turbomachinery, 128(3):413-422.

[10] De Maesschalcka C, Lavagnoli S, Paniagua G, Vinha N. (2014) Aerothermodynamics of tight rotor tip clearance flows in high-speed unshrouded turbines., Applied Thermal Engineering, 65(1-2):343-351.

[11] Borm O, Kau H-P. (2012) Unsteady Aerodynamics of a Centrifugal Compressor Stage: Validation of Two Different CFD Solvers, ASME Turbo Expo Turbine Technical Conference and Exposition Volume 8: Turbomachinery

[12] Malael I, Dumitrescu H, Dumitrache A. (2011) Methods for Improve the Performance of the Turbomachines Using the Flow Control, AIP Conf. Proc. 1389, 1515.

[13] Rinaldi E, Raspopov RS, Colonna P, Pecnik R. (2014) Modeling Curvature Effects on Turbulence Transition for Turbomachinery Flows, Vol 2B: Turbomachinery

[14] ** Numeca Fine/Turbo 9.1 User Manual

[15] Sundén B, Brebbi CA. (2014) Heat Transfer XIII: Simulation and Experiments in Heat and Mass Transfer, WIT Transatction on Engineering Sciences, WIT Press, 83:221.

[16] Bathe KJ (1996) Finite Element Procedures, Prentice Hall, New Jersey 07632.

[17] ** ANSYS ICEM CFD Help Manual (2012), ANSYS ICEM CFD 14.5,pp.425

[18] Roache PJ (1997) Quantification of uncertainty in computational fluid dynamics. Annu. Rev. Fluid. Mech., 29:123-160.

[19] Walsh P, Fletcher P. (2004) Gas Turbine Performance, John Wiley \& Sons. ISBN:0-63206434-X, pp. 163

[20] Boyce MP. (2012) Gas Turbine Engineering Handbook, Elsevier, ISBN: 987-0-12-3838421, pp. 162 
[21] Vogt D. (2007) Course MJ2429 EfficienciesTurbomachinery Lecture Notes, KTH University

[22] Aungier RH. (2000) Centrifugal Compressors: A strategy for Aerodynamic Design and analysis. ASME Press.

[23] Harley P, Spence S, Filsionger D, Dietrich M, Early J. (2015) Experimental and numerical benchmarking of an improved mean line modeling method for automotive turbocharger centrifugal compressors. ASME proceedings Radial Turbomachinery Aerodynamics, GT 2015-42175,

[24] Klausner E, Gampe U. (2014) Evaluation and Enhancement of a One-Dimensional Performance Analysis Method for Centrifugal Compressors, Volume 2D: Turbomachinnery, ISBN: 978-0-7918-4563-9

[25] Dixon SL, Hall CA. (2014)Fluid Mechanics, Thermodynamics of Turbomachinery -7 th Edition, Elsevier Butterworth-Heinemann, ISBN: 0124159540

[26] Casey MV, Robinson CJ. (2011) A Method to Estimate the Performance of a Centrifugal Compressor Stage Proceedings of ASME Turbo Power for Land, Sea and Air,

[27] Rodgers C. (1991) The Efficiencies of Single-Stage Centrifugal Compressors for Aircraft Applications, International Gas Turbine and Aeroengine Congress and Exposition

\section{NOMENCLATURE}

$C_{p}$

$D_{2}$

$\dot{m}$

$M$

N.S.

Paero

$R_{\text {air }}$

$\mathrm{T}_{1}^{*}$

$\mathrm{T}_{2}^{*}$

$\gamma$

$\Delta T^{*}$

$\eta_{\text {isent }}^{*}$

$\eta_{\text {poly }}^{*}$

$\pi_{C}^{*}$

$\varphi$

$\omega-$ specific heat at constant pressure $[\mathrm{J} /(\mathrm{mol} \cdot \mathrm{K}]$

Impeller peripheral diameter

fluid mass flow $[\mathrm{kg} / \mathrm{s}]$

torque $[\mathrm{N} \cdot \mathrm{m}]$

specific speed of the impeller

power absorbed by the aerodynamic process [W]

Air gas constant $[\mathrm{J} / \mathrm{kg} \cdot \mathrm{K}]$

total inlet temperature [K]

total temperature at considered outlet [K]

adiabatic exponent (specific heat ratio)

total temperature difference between considered outlet and inlet [K]

total to total isentropic efficiency

total to total polytropic efficiency

total to total pressure ratio

flow coefficient

angular velocity $[\mathrm{rad} / \mathrm{s}]$ 